Valdivia López, Marcos y Juan R. Cuadrado-Roura, coordinadores (2017) La economía de las actividades creativas. Una perspectiva desde España y México. Universidad Nacional Autónoma de México, Centro Regional de Investigaciones Multidisciplinarias; Universidad de Alcalá (Coeditores). México-España.

ISBN UNAM: 978-607-02-9540-9

ISBN UAH: 978-84-16978-34-2
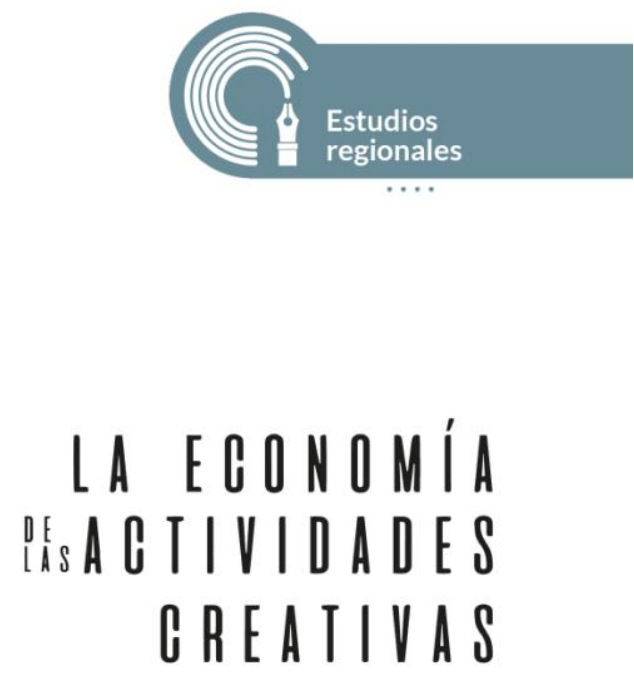

UNA PERSPECTIVA DESDE

ESPANA Y MEXICD

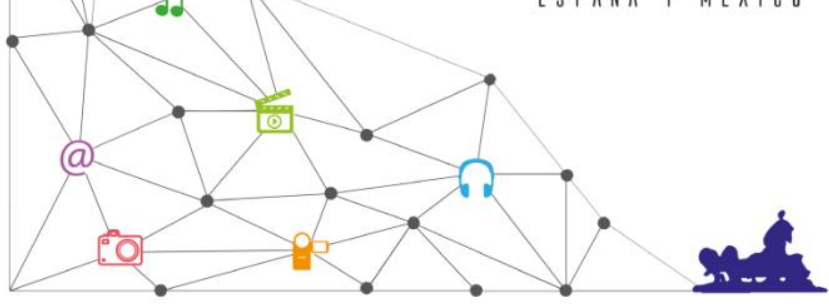

Marcos Valdivia López Juan R. Cuadrado-Roura Coordinadores 


\section{LA ECONOMÍA DE LAS ACTIVIDADES CREATIVAS. UNA PERSPECTIVA DESDE ESPAÑA Y MÉXICO}

\section{PROEMIO}

Las actividades económicas denominadas creativas se han convertido en uno de los ejes centrales del desarrollo regional y urbano en múltiples y diversos territorios del planeta. En este libro se analiza la manera en que estas actividades están presentes e impactan en el crecimiento y desarrollo económico de las regiones de España, México y otros países afines. La economía de las actividades creativas se ha estudiado primordialmente en países desarrollados del norte de Europa y América; por lo que esta obra representa un valioso esfuerzo analítico para abordar el tema desde España y México, realidades distantes en lo geográfico pero cercanas en herencia y transmisión cultural.

El libro contiene dieciocho capítulos que reúnen a treinta y cinco expertos en el tema provenientes de diversas universidades y centros de investigación de España, México, Ecuador, Italia y Turquía. Consta de seis partes en las que se discuten aspectos relacionados con la economía de las actividades creativas: medición; aglomeración y localización; actividad empresarial y exportaciones; mercados laborales; productividad y externalidades; y gobernanza, creatividad mediterránea y transculturación. El propósito de presentar estos estudios es contribuir a su conocimiento en regiones que pertenecen al ámbito iberoamericano, para así motivar el debate sobre las coincidencias y divergencias que puedan existir con las dinámicas que prevalecen en los países desarrollados del norte hemisférico.

CONCEPTOS CLAVE: Industrias Creativas y Culturales, Conocimiento, Externalidades 